\title{
Pertanggungjawaban Pidana Korporasi Terhadap Pencemaran Lingkungan (Studi Pada Perseroan Terbatas Jagad Raya Tama)
}

\author{
Corporate Criminal Liability for Environmental Pollution (Study at PT Jagad \\ Raya Tama)
}

\section{Dedi Arman}

Kongres Advokad Indonesia (KAI)

E-mail: dedyarmanforak@gmail.com

\author{
Oheo K. Haris \\ Pascarjana Universitas Halu Oleo \\ E-mail:oheokh@gmail.com \\ Sabrina Hidayat \\ Pascarjana Universitas Halu Oleo \\ E-mail: sabrinahidayat@uho.ac.id
}

\begin{abstract}
Corporate crime against environmental pollution is an act of great crime and is very dangerous as well as threatening the lives of humans, animals and plants. Based on normative juridical research, with the statutory approach (statue approch), and case (case approch), what has been done can be concluded that the case that occurred at PT Jagat Raya Tama is related to environmental issues namely the problem of water pollution in rivers that have health impacts to the community, so accountability is required in accordance with applicable law. Corporate criminal liability for environmental pollution is clearly regulated in Law Number 32 of 2009 concerning Environmental Protection and Management. Provisions regarding corporate criminal liability are regulated in the Law on environmental management contained in articles 97 to article 120. This also serves as a reference for law enforcers in upholding the rule of law in corporate criminal acts against environmental pollution.
\end{abstract}

Keyword: Liability; Corporate; Environmental Pollution

Abstrak: Kejahatan korporasi terhadap pencemaran lingkungan hidup merupakan tindakan kejahatan besar dan sangat berbahaya sekaligus mengancam kehidupan manusia, hewan dan tumbuhan. Berdasarkan penelitian yuridis normatif, dengan pendekatan undang-undang (statue approch), dan kasus (case approch), yang telah dilakukan dapat disimpulkan bahwa kasus yang terjadi di PT Jagat Raya Tama adalah menyangkut persoalan lingkungan yakni masalah pencemaran air di sungai yang mempunyai dampak kesehatan terhadap masyarakat, sehingga diperlukan pertanggungjawabannya sesuai dengan undang-undang yang berlaku. 
Pertanggungjawaban pidana korporasi terhadap pencemaran lingkungan secara jelas diatur dalam Undang-Undang Republik Indonesia Nomor 32 Tahun 2009 Tentang Perlindungan dan Pengelolaan Lingkungan Hidup. Ketentuan mengenai pertanggungjawaban pidana korporasi diatur dalam Undang-Undang pengelolaan lingkungan hidup terdapat pada Pasal 97 sampai dengan Pasal 120. Hal tersebutsekaligus menjadi acuan para penegak hukum dalam menegakkan supremasi hukum pada tindakan kejahatan korporasi terhadap pencemaran lingkungan.

Kata kunci: Pertanggungjawaban; Korporasi; Pencemaran Lingkungan

\section{PENDAHULUAN}

Dalam rangka melaksanakan pembangunan yang berwawasan lingkungan dan kesadaran bahwa masalah lingkungan adalah masalah tanggung jawab terhadap kepentingan generasi mendatang, seperti yang di amanatkan dalam Undang-Undang Republik Indonesia Nomor 32 Tahun 2009 tentang Perlindungan dan Pengelolaan Lingkungan Hidup dan Peraturan Pemerintah Nomor 27 Tahun 2009 tentang Analisis Mengenai Dampak Lingkungan (AMDAL) Peraturan Menteri Negara Lingkungan Hidup Nomor 5 Tahun 2012 Tentang Jenis Rencana Usaha Dan/Atau Kegiatan Yang Wajib Dilengkapi Dengan Analisis Mengenai Dampak Lingkungan Hidup. ${ }^{1}$ Setiap kegiatan pembangunan di Indonesia, baik dalam proses perencanaan maupun pada proses operasionalnya haruslah memperhatikan aspek lingkungan, sebagaimana yang diamanatkan dalam Undang-Undang Republik Indonesia Nomor 32 tahun 2009 tentang Perlindungan dan Pengelolaan Lingkungan Hidup. Dalam implementasinya, dibutuhkan suatu instrumen pengelolaan lingkungan sebagaimana yang dituangkan dalam Peraturan Pemerintah Republik Indonesia Nomor 27 Tahun 2012 Tentang Izin Lingkungan.

Korporasi sebagai suatu entitas atau subjek hukum yang keberadaannya memberikan kontribusi yang besar dalam meningkatkan pertumbuhan ekonomi dan pembangunan nasional, namun dalam kenyataannya korporasi ada kalanya juga melakukan pelbagai tindak pidana (corporate crime) yang membawa dampak kerugian terhadap negara dan masyarakat. ${ }^{2}$ Kegiatan eksploitasi sumber daya alam seperti industri pertambangan merupakan salah satu industri yang secara finansial sangat menguntungkan untuk perekonomian negara karena memiliki daya jual yang tinggi di pasaran global. Kegiatan pertambangan apabila dilakukan di kawasan hutan dapat merusak ekosistem hutan. Apabila tidak dikelola dengan baik,

1 Undang-Undang Republik Indonesia Nomor 32 Tahun 2009 Tentang Perlindungan dan Pengelolaan Lingkungan Hidup (Lembaran Negara Republik Indonesia Tahun 2009 Nomor 140, Tambahan Lembaran Negara Republik Indonesia Nomor 5059).

2 Konsiderans huruf a Peraturan Mahkamah Agung Nomor 13 Tahun 2016 tentang Tata Cara Penanganan Perkara Tindak Pidana oleh Korporasi. 
penambangan dapat menyebabkan kerusakan lingkungan secara keseluruhan dalam bentuk pencemaran air, tanah, dan udara. ${ }^{3}$

Hukuman-hukuman yang dapat dijatuhkan kepada badan hukum atau perkumpulan tersebut misalnya hukuman denda, pencabutan izin, pembubaran, ganti rugi, keharusan berbuat sesuatu, pernyataan permintaan maaf kepada rakyat atau kepada pihak lain yang telah dirugikan, atau pencabutan hak-hak tertentu lainnya. ${ }^{4}$ Pada kenyataannya bahwa untuk memulihkan lingkungan yang telah rusak atau tercemar tidak akan pernah bisa mengembalikan posisi lingkungan yang sebelumnya, ini karena aturan pertambangan dimulai dari penerbitan izin dimana di dalamnya tertuang prosedur sebelum melakukan aktivitas penambangan dimulai dari ruang lingkup pada pedoman pertambangan melalui Keputusan Menteri Energi Dan Sumber Daya Mineral Republik Indonesia Nomor 1827 K/30/MEM/2018 mengenai eksplorasi, studi kelayakan konstruksi dan pengujian alat pertambangan (commisioning), pemanfaatan teknologi pertambangan, pemasangan tanda batas penambangan, pengolahan dan/atau pemurnian, pengangkutan, dan pengelolaan teknik pasca tambang serta rencana reklamasi.

Hampir semua Korporasi dalam hal ini yang melakukan usaha kegiatan penambangan areal konsesi tambang di Sulawesi Tenggara khususnya di Konawe Selatan dalam mengubah alam tidak mengacu pada aturan penambangan (AMDAL) sehingga proses kerusakan lingkungan semakin parah. Kejahatan korporasi merupakan kejahatan organisasi yang terjadi dalam konteks saling keterkaitan yang sangat kompleks. Oleh karenanya, istilah "kejahatan korporasi" disebut juga dengan istilah "kejahatan organisasi" (organizational crime). ${ }^{5}$ UndangUndang Republik Indonesia Nomor 11 Tahun 1967 tentang Ketentuan-ketentuan Pokok Pertambangan tidak mencantumkan secara eksplisit pengaturan tentang pencegahan dan pemulihannya untuk daerah sekitar tambang. Undang-Undang Republik Indonesia Nomor 4 Tahun 2009 tentang Pertambangan Mineral dan Batu Bara, mulai membuka cakrawala baru tentang aspek yuridis tentang pengelolaan pertambangan Indonesia. Dari aspek lingkungan Undang-Undang tersebut mulai mengakomodasi beberapa permasalahan lingkungan walau secara prinsip lingkungan masih banyak yang terlewati apalagi kalau berkaca pada gagasan yang sesuai dengan mata rantai (regulatory chain) pengelolaan lingkungan yang dijabarkan oleh

\footnotetext{
Fahruddin, Pengelolaan Limbah Pertambangan Secara Biologis: Biological Management of Mining Waste, Makassar: Celebes Media Perkasa, 2018, hlm. 65.

4 Munir Fuady, Teori Besar (Grand Theory) Dalam Hukum, Jakarta: Kencana, 2013, hlm. 196.

5 Muhammad Topan, Kejahatan Korporasi Dibidang Lingkungan Hidup, Cet: I, Bandung: Nusa Media, 2009, hlm. 42.
} 
R. Seerden. M. Heldeweg6, pengelolaan lingkungan merupakan mata rantai (regulatory chain) yang meliputi: legislation, regulation, issueing permit, implementation, and enforcement.

Pencemaran dan perusakan lingkungan tidak hanya menjadi masalah nasional saja, tetapi telah menjadi masalah antar negara, regional dan global. Dunia semakin sempit, hubungan antar negara bertambah dekat dan ada ketergantungan antara negara yang satu dengan yang lainnya. Akibat yang timbul dari masalah lingkungan kadang telah melintasi batasbatas negara, dalam bentuk pencemaran air sungai, emisi udara, kebakaran hutan, pencemaran minyak di laut, dan banyak lagi yang lainnya. Pemerintah Kabupaten Konawe Selatan menyadari bahwa kekayaan alam merupakan anugerah Tuhan Yang Maha Esa, wajib dilestarikan dan dikembangkan sebagai sumber penunjang taraf hidup manusia dan makhluk lain demi kelangsungan dan kemakmuran serta peningkatan kualitas kehidupan itu sendiri. Hal tersebut sejalan apa yang dituangkan dalam Amanat Undang-Undang 1945 yang menyatakan bahwa Bumi, air, serta kekayaan alam lainnya yang terkandung di dalamnya dikuasai oleh negara dan dipergunakan sebesar-besarnya untuk kemakmuran rakyat. Bahwa untuk memberikan pedoman pelaksanaan kaidah teknik pertambangan yang baik, serta untuk melaksanakan ketentuan Peraturan Menteri Energi dan Sumber Daya Mineral Nomor 26 Tahun 2018 tentang Pelaksanaan Kaidah Teknik Pertambangan Yang Baik Dan Pengawasan Pertambangan Mineral Dan Batu Bara. Kajian tentang Pasal 33 Undang-Undang 1945 dijadikan dasar dalam pengelolaan pertambangan di Indonesia khususnya di Sulawesi Tenggara. Bahkan menjadi isu yang usang dan lebih bermotif keadilan ekonomi dari pada keadilan ekologi. Memang dapat dilihat dari beberapa aspek pengelolaan ekonomi yang berhubungan atau berbasiskan penggunaan lahan atau sumber daya alam selalu mengesampingkan aspek lingkungan.

Dalam konteks sosial budaya di Kecamatan Palangga Kabupaten Konawe Selatan terlihat mulai tergusurnya nilai-nilai budaya dan kearifan lokal diganti dengan hadirnya alat-alat berat yang bergerak tanpa batas dan suara bising serta polusinya. Masyarakat yang dulu lebih senang berkebun dan bertani dengan budaya guyubnya digantikan dengan buruh-buruh tani yang bekerja di areal pertambangan yang lebih menjanjikan secara ekonomi dan pendek dari pada bekerja di ladang atau sawah. Hal ini juga didukung dengan kebijakan dibidang pertanian dan pangan yang lebih berorientasi pasar dan hasil. Pengelolaan lingkungan hidup yang berpotensi tambang nikel yang dilakukan oleh berbagai perusahaan di wilayah Konawe Selatan Kecamatan Palangga yang pada awalnya harapan masyarakat dapat berubah ekonomi serta meningkatkan

6 Rene J.G.H. Seerden dan Michael A. Heldeweg, dalam Siti Sundari Rangkuti, Hukum Lingkungan dan Kebijaksanaan Lingkungan Nasional, Cetakan III, Surabaya: Airlangga University Press, 2003, hlm. 430. 
taraf hidup pemilik lahan, serta masyarakat wilayah tambang dimana masyarakat dapat bekerja melalui lapangan pekerjaan yang ditawarkan oleh perusahaan serta kompensasi lahan, ganti rugi tanaman dan lain-lain.

Investor yang hanya mengandalkan selebaran kertas yaitu Ijin Usaha Produksi (IUP) yang dikantongi oleh korporasi atau perusahaan lalu mengesampingkan tanggung jawab hukum dimana pengusaha melakukan pembongkaran hutan, gunung demi pemuas nafsu keuntungan yang besar. Perilaku dan tindakan korporasi tersebut di atas tidak lagi berpedoman pada Undang-Undang Republik Indonesia Nomor 32 Tahun 2009 tentang Perlindungan Dan Pengelolaan Lingkungan Hidup. ${ }^{7}$ Kondisi daratan yang sudah menggundul di areal Konsesi tambang nikel berdampak pada Pencemaran Lingkungan dimana ketika hujan turun maka limbah tanah, lumpur, serta minyak bahan bakar yang dari pegunungan mengalir ke sungai yang ada di lingkaran pemukiman warga. Areal konsesi tambang nikel di Kecamatan Palangga sangat memprihatinkan, dimana perusahaan sebagai pihak yang bertanggungjawab dalam proses penambangan di wilayah IUP tersebut tidak menerapkan pembuatan kantong lumpur, sehingga lumpur tersebut tidak terserap baik.

PT. Jagad Raya Tama merupakan salah satu perusahaan yang bergerak di bidang pertambangan nikel. PT. Jagad Raya Tama terletak di Kecamatan Palangga Kabupaten Konawe Selatan dengan luas areal pertambangan nikel 1.757 hektar. Berdasarkan ijin Bupati Konawe Selatan Tahun 2010.PT. Jagad Raya Tama tersebut bukan saja menimbulkan pencemaran lingkungan. Berdasarkan uraian tersebut di atas" penulis melakukan penelitian berjudul "Pertanggungjawaban Pidana Korporasi Terhadap Pencemaran lingkungan (studi pada perseroan terbatas Jagad Raya Tama). Dalam pengelolaan dan pengawasan pertambangan (korporasi), penggunaan wewenang mempunyai kaitan erat dengan kebijakan. Pemberian izin pertambangan merupakan keputusan pejabat berwenang. Sifat keputusan ini dapat dikaji melalui karakter wewenang distribusi. ${ }^{8}$

\section{METODE PENELITIAN}

Jenis penelitian yang digunakan dalam penulisan ini adalah penelitian yuridis normatif, yaitu melakukan penelitian dengan cara menelaah berdasarkan kaidah-kaidah dan norma hukum,

\footnotetext{
7 Undang-Undang Republik Indonesia Nomor 4 Tahun 2009 Tentang Pertambangan Mineral Dan Batubara (Lembaran Negara Republik Indonesia Tahun 2009 Nomor 4, Tambahan Lembaran Negara Republik Indonesia Nomor 4959).

8 Oheo K. Haris, “Aspek Hukum Pidana Dalam Kaitannya Dengan Perizinan Di Bidang Pertambangan”. Jurnal Yuridika, Volume 29 No. 3, September-Desember 2014, hlm. 352.
} 
serta mengumpulkan data dari literatur, makalah, koran dan majalah sesuai kasus yang diangkat. Menurut Peter Mahmud Marzuki penelitian hukum normatif adalah suatu proses untuk menemukan suatu aturan hukum, prinsip-prinsip hukum, maupun doktrin-doktrin hukum untuk menjawab permasalahan hukum yang dihadapi. ${ }^{9}$ Metode penelitian normatif, yaitu penelitian yang menggunakan bentuk legis positivis yang menyatakan bahwa hukum adalah identik dengan norma-norma tertulis yang dibuat dan diundangkan oleh lembagalembaga atau pejabat yang berwenang. ${ }^{10}$ Sedangkan pendekatan yang digunakan adalah peraturan Perundang-Undangan (statute approach), konseptual (conceptual approach), dan Pendekatan kasus (case approach). Pendekatan peraturan Perundang-Undangan (statute approach) yaitu dengan menelusuri setiap peraturan perundang-undangan yang mengatur mengenai korporasi dan tindak pidana lingkungan. Pendekatan konseptual (conceptual approach) yaitu gabungan Antara asas hukum dan doktrin para ahli pidana, terkhusus mengenai tindak pidana lingkungan dan konsep kejahatan korporasi dan pertanggung jawaban pidana korporasi dan Pendekatan kasus (case approach) yaitu dengan mencari kasus atau suatu putusan mengenai tindak pidana lingkungan untuk memperkuat argumentasi dan memberikan perbandingan solusi dari adanya permasalahan hukum.

\section{ANALISIS DAN PEMBAHASAN}

\section{Pertanggungjawaban Pidana Korporasi Yang Melakukan Pencemaran Lingkungan Berdasarkan Konsep Konservasi Lingkungan Hidup}

Pertanggungjawaban korporasi diatur di berbagai undang-undang seperti Undang-Undang tentang Pertambangan, Mineral dan Batubara, Undang-Undang tentang Kehutanan, UndangUndang tentang Lingkungan Hidup, Undang-Undang tentang Tata Ruang, Undang-Undang tentang Pemberantasan Tindak Pidana Korupsi, Undang-Undang tentang Tindak Pidana Pencucian Uang, Undang-Undang tentang Kepabeanan, dan lain sebagainya. Pengaturan yang sangat beragam menunjukkan politik hukum yang belum jelas misalnya dalam hal pemberian definisi, ruang lingkup tindak pidana, dan jenis sanksi pidana terhadap korporasi. Bahkan dalam hal perumusan pertanggungjawaban pidana korporasi dari berbagai perundang-undangan tersebut berbeda. Ada sebagian yang membebankan kepada salah satu di antara pengurus atau

9 Peter Mahmud Marzuki, Penelitian Hukum, Jakarta: Kencana, 2008, hlm. 35.

10 Sabrina Hidayat, "Tinjauan Yuridis Kewenangan Komisi Pemberantasan Korupsi Melakukan Penyidikan Penggabungan Perkara Tindak Pidana Korupsi dan Pencucian Uang”. Halu Oleo Law Review, Volume 1 Issue 2, September 2017, hlm. 183. 
korporasi saja dan ada pula yang menetapkan kedua-duanya dapat dituntutkan pertanggungjawaban pidananya secara bersamaan.

Ketidakjelasan pengaturan pertanggungjawaban pidana korporasi dalam perundangundangan di atas, menjadi salah satu kendala utama penegakan hukum dalam rangka pemberantasan tindak pidana korporasi. Misalnya dalam perkara tindak pidana korupsi, meskipun korporasi telah ditetapkan sebagai subjek hukum dan dapat dipertanggungjawabkan secara pidana sejak tahun 1999 (dimana Undang-Undang tentang Pemberantasan Tindak Pidana Korupsi mulai diberlakukan), tetapi sampai dengan tahun 2010 (sekitar 11 tahunan) belum pernah muncul perkara korupsi dimana korporasi dijadikan sebagai terdakwa dan dituntut serta dipidana. Baru dalam perkara PT. Giri Jaladhi Wana yang diajukan sebagai terdakwa oleh Kejaksaan dan dituntut ke pengadilan tindak pidana korupsi. ${ }^{11}$

Keberhasilan Jaksa dalam menuntutkan pertanggungjawaban pidana di peradilan ini didukung dengan perangkat kebijakan Penegak hukum berupa Surat Edaran Kejaksaan Agung RI Nomor B-36/A/Ft.1/06/2009 perihal Korporasi Sebagai Tersangka/Terdakwa Dalam Tindak Pidana Korupsi. Tanpa panduan dari surat edaran tersebut, perkara ini juga tidak akan muncul ke permukaan karena secara teknis hukum acara penanganan tindak pidana korporasi masih belum jelas. Kejaksaan Agung selanjutnya menyempurnakan Surat Edaran tersebut menjadi Peraturan Jaksa Agung Republik Indonesia Nomor: Per-028/A/JA/10/2014 tentang Pedoman Penanganan Perkara Pidana Dengan Subjek Hukum Korporasi. ${ }^{12}$

Seiring sejalan dengan Kejaksaan Agung di atas, Mahkamah Agung menerbitkan Peraturan Mahkamah Agung Nomor 13 Tahun 2016 tentang Tata Cara Penanganan Perkara Tindak Pidana Oleh Korporasi. Peraturan Mahkamah Agung ini memberikan definisi khusus terkait tindak pidana Korporasi yaitu tindak pidana yang dilakukan oleh orang berdasarkan hubungan kerja, atau berdasarkan hubungan lain, baik sendiri-sendiri maupun bersama-sama yang bertindak untuk dan atas nama Korporasi di dalam maupun di luar Lingkungan Korporasi. ${ }^{13}$

Peraturan Mahkamah Agung Nomor 13 Tahun 2016 tentang Tata Cara Penanganan Perkara Tindak Pidana Oleh Korporasi juga menentukan bahwa dalam menjatuhkan pidana

11 Budi Suharyanto, "Pertanggungjawaban Pidana Korporasi Berdasarkan Corporate Culture Model dan Implikasinya", Jurnal Rechtsvinding, Volume 6, Nomor 3, Desember 2017. hlm. 207.

12 Peraturan Mahkamah Agung Nomor 13 Tahun 2016 tentang Tata Cara Penanganan Perkara Tindak Pidana Oleh Korporasi.

13 Peraturan Mahkamah Agung Nomor 13 Tahun 2016 tentang Tata Cara Penanganan Perkara Tindak Pidana Oleh Korporasi. 
terhadap Korporasi, Hakim dapat menilai kesalahan Korporasi antara lain: (a). Korporasi dapat memperoleh keuntungan atau manfaat dari tindak pidana tersebut atau tindak pidana tersebut dilakukan untuk kepentingan Korporasi; (b). Korporasi membiarkan terjadinya tindak pidana; atau (c). Korporasi tidak melakukan langkah-langkah yang diperlukan untuk melakukan pencegahan, mencegah dampak yang lebih besar dan memastikan kepatuhan terhadap ketentuan hukum yang berlaku guna menghindari terjadinya tindak pidana. Keberadaan Peraturan Mahkamah Agung Nomor 13 Tahun 2016 tentang Tata Cara Penanganan Perkara Tindak Pidana Oleh Korporasi telah menjadi angin segar bagi penegak hukum untuk semakin yakin dalam menindak korporasi yang melakukan tindak pidana. Berbeda halnya dengan perspektif Pengusaha yang khawatir mengenai penetapan pertanggungjawaban korporasi atas apa yang dilakukan oleh Pengurusnya, karena bisa saja Pengurusnya melakukan kejahatan yang tidak ada kaitannya dengan korporasi namun pertanggungjawaban atas kejahatan tersebut dibebankan kepada korporasi. Implikasi atas dipidananya korporasi tersebut adalah kerugian masyarakat, khususnya yang memiliki saham atas perusahaan publik yang dibebankan pertanggung jawaban pidana. Apalagi Peraturan Mahkamah Agung Nomor 13 Tahun 2016 tentang Tata Cara Penanganan Perkara Tindak Pidana Oleh Korporasi tidak memberikan perlindungan terhadap pemegang saham atas perusahaan publik yang dibebankan pertanggungjawaban pidana. ${ }^{14}$

Pengaturan dalam Peraturan Mahkamah Agung Nomor 13 Tahun 2016 tentang Tata Cara Penanganan Perkara Tindak Pidana Oleh Korporasi yang menentukan bahwa kesalahan dapat dibebankan di saat korporasi membiarkan terjadinya tindak pidana ini menjadi hal yang mengkhawatirkan bagi kalangan pengusaha. Jadi meskipun tidak secara nyata terbukti menguntungkan korporasi dan sepenuhnya menguntungkan pribadi Pengurus tetapi ternyata ditemukan bukti bahwa korporasi tidak mencegah tindak pidana Pengurus tersebut maka juga dapat dikenakan pertanggungjawaban pidananya kepada Korporasi. Termasuk juga dapat dipersalahkan bilamana Korporasi tidak melakukan langkah-langkah yang diperlukan untuk melakukan pencegahan, dampak yang lebih besar dan memastikan kepatuhan terhadap ketentuan hukum yang berlaku guna menghindari terjadinya tindak pidana.

Dalam tindak pidana lingkungan bagi korporasi, Undang-Undang Republik Indonesia Nomor 32 Tahun 2009 tentang Perlindungan dan Pengelolaan Lingkungan Hidup mengatur hal-

14 Hariyadi B. Sukamdani, Korporasi sebagai Subyek Hukum Pidana Pasca Perma No.13 Tahun 2016: Pandangan Dunia Usaha, Makalah seminar dalam Rangka HUT IKAHI ke-64 tahun di Hotel Mercure Ancol Jakarta pada hari Selasa 21 Maret 2017, hlm. 7. 
hal antara lain: (1) Apabila tindak pidana lingkungan hidup dilakukan oleh, untuk, atau atas nama badan usaha, tuntutan pidana dan sanksi pidana dijatuhkan kepada: (a) badan usaha; dan/atau; (b) orang yang memberi perintah untuk melakukan tindak pidana tersebut atau orang yang bertindak sebagai pemimpin kegiatan dalam tindak pidana tersebut. (2) Apabila tindak pidana lingkungan hidup dilakukan oleh orang, yang berdasarkan hubungan kerja atau berdasarkan hubungan lain yang bertindak dalam lingkup kerja badan usaha, sanksi pidana dijatuhkan terhadap pemberi perintah atau pemimpin dalam tindak pidana tersebut tanpa memperhatikan tindak pidana tersebut dilakukan secara sendiri atau bersama-sama. ${ }^{15}$ (3) Jika tuntutan pidana diajukan kepada pemberi perintah atau pemimpin tindak pidana, ancaman pidana yang dijatuhkan berupa pidana penjara dan denda diperberat dengan sepertiga. (4) Terhadap tindak pidana badan hukum, sanksi pidana dijatuhkan kepada badan usaha yang diwakili oleh pengurus yang berwenang mewakili di dalam dan di luar pengadilan sesuai dengan peraturan perundang-undangan selaku pelaku fungsional. (5) Badan usaha dapat dikenakan pidana tambahan atau tindakan tata tertib berupa:

(a) perampasan keuntungan yang diperoleh dari tindak pidana;

(b) penutupan seluruh atau sebagian tempat usaha dan/atau kegiatan;

(c) perbaikan akibat tindak pidana;

(d) kewajiban mengerjakan apa yang dilalaikan tanpa hak; dan/atau

(e) penempatan perusahaan di bawah pengampuan paling lama 3 (tiga) tahun. Sanksi bagi Tindak pidana lingkungan secara jelas telah diatur dalam Undang-Undang Republik Indonesia Nomor 32 Tahun 2009 Tentang Perlindungan dan Pengelolaan Lingkungan Hidup. Hal yang memberikan perbedaan dengan sanksi pidana biasa pada tindak pidana lingkungan terdapat pada pidana tambahan dan pengkajian lebih lanjut antara lain:

(1) Perampasan keuntungan yang diperoleh dari tindak pidana belum terdapat pengaturan lebih tegas mengenai manfaat dan peruntukan perampasan keuntungan yang dimaksud.

(2) Penutupan seluruh atau sebagian tempat usaha dan/atau kegiatan sebenarnya dapat juga dijatuhkan melalui sanksi administrasi yaitu pencabutan izin usaha melalui Pengadilan Tata usaha Negara.

15 Undang-Undang Republik Indonesia Nomor 32 Tahun 2009 Tentang Perlindungan dan Pengelolaan Lingkungan Hidup (Lembaran Negara Republik Indonesia Tahun 2009 Nomor 140, Tambahan Lembaran Negara Republik Indonesia Nomor 5059). 
(3) Perbaikan akibat tindak pidana masih belum dapat didefinisikan secara jelas mengingat perbaikan akibat tindak pidana khususnya bagi kerusakan lingkungan menjadi tidak terukur dan dapat menjadi tumpang tindih dengan kewajiban pemulihan lingkungan pada penegakan hukum perdata;

(4) Kewajiban mengerjakan apa yang dilalaikan tanpa hak cukup sulit didefinisikan, dikarenakan dalam pencemaran berat atau perusakan lingkungan cenderung fungsi lingkungan akan sulit untuk dipulihkan ke keadaan semula.

(5) Penempatan perusahaan di bawah pengampuan paling lama 3 (tiga) tahun dalam pelaksanaannya diperlukan manajer lingkungan yang bertugas mengembalikan fungsi manajemen lingkungan korporasi sebagaimana sebelum terjadi pencemaran atau perusakan, pada dasarnya sanksi tambahan ini ditujukan untuk tetap menjaga keberlangsungan kegiatan korporasi, namun bentuk dan pengaturannya belum secara tegas dan diatur dalam peraturan perundang-undangan.

Ketentuan mengenai tanggung jawab bagi korporasi dalam tindak pidana lingkungan telah diatur dalam Undang-Undang Republik Indonesia Nomor 40 Tahun 2007 tentang Perseroan Terbatas yang menyatakan Direktur Perusahaan tidak dapat melepaskan dirinya dari pertanggungjawaban pidana dalam hal perusahaan yang dipimpinnya mencemari dan atau merusak lingkungan. Tanggung Jawab Sosial dan Lingkungan adalah komitmen Perseroan untuk berperan serta dalam pembangunan ekonomi berkelanjutan guna meningkatkan kualitas kehidupan dan lingkungan yang bermanfaat, baik bagi Perseroan sendiri, komunitas setempat, maupun masyarakat pada umumnya penjelasan pasal 1 undang-undang nomor 40 tahun 2007 tentang perseroan terbatas adalah badan hukum yang merupakan persekutuan modal, didirikan berdasarkan perjanjian melakukan kegiatan usaha dengan modal dasar yang seluruhnya terbagi saham,dan memenuhi persyaratan tang ditetapkan dalam undangundang. ${ }^{16}$

Dalam penanganan perkara tindak pidana umum dan tindak pidana khusus terkait keberadaan korporasi sebagai subjek hukum yang menjadi tersangka/terdakwa telah dikeluarkan Peraturan Jaksa Agung RI No: PER-028/A/JA/10/2014, tanggal 1 Oktober 2014

16 Pasal 1 ayat (1) Undang-Undang Republik Indonesia Nomor 40 Tahun 2007 tentang Perseroan Terbatas (Lembaran Negara Republik Indonesia Tahun 2007 Nomor 106, Tambahan Lembaran Negara Republik Indonesia Nomor 4756). 
tentang Pedoman Penanganan Perkara Pidana dengan Subjek Hukum Korporasi. ${ }^{17}$ Pada tanggal 29 Desember 2016, diberlakukan Peraturan Mahkamah Agung Nomor 13 Tahun 2016 tentang Tata Cara Penanganan Perkara Tindak Pidana oleh Korporasi. Secara substansi hukum, Peraturan Mahkamah Agung ini mengatur definisi dan identifikasi tindak pidana korporasi, pertanggungjawaban pidananya beserta teknis pemeriksaan korporasi baik di tingkat penyidikan, penuntutan, persidangan hingga eksekusinya. ${ }^{18}$

\section{Tindak Pidana Lingkungan Oleh Korporasi Berdasarkan Asas Subsidaritas}

Asas subsidiaritas adalah asas yang menyatakan bahwa hukum pidana seyogyanya digunakan sebagai langkah akhir. Asas yang termuat pada bagian penjelasan umum Undang-Undang Republik Indonesia Nomor 23 Tahun 1997 tentang Pengelolaan Lingkungan Hidup (PLH) ini, mensyaratkan tiga hal yang harus terpenuhi sebelum hukum pidana diterapkan. Menurut Soeseno Sigid bahwa dengan banyaknya industri atau kegiatan usaha yang mendapat izin dari pemerintah, ternyata melakukan pencemaran atau perusakan lingkungan hidup. Hal tersebut di dasari pada para pelaku bisnis yang merasa tidak bersalah dan membenarkan bahwa perusahaan tersebut telah mendapat izin dari pemerintah. Sementara salah-satu syarat untuk mendapat izin usaha adalah adanya rekomendasi tentang analisis mengenai dampak lingkungan termasuk di dalamnya juga mengenai rencana pengelolaan lingkungan (RKL) dan rencana pemantauan lingkungan (RPL). ${ }^{19}$

Model penegakan hukum dengan mengoptimalkan penerapan pidana administrasi ini memiliki banyak keuntungan. Antara lain:

1. Akan memudahkan bagi penegak hukum dalam melakukan pembuktian perkara disebabkan bentuk rumusan delik yang dibuat pada umumnya adalah delik formil;

2. Pada hakikatnya ketika perbuatan-perbuatan dalam rangka persiapan untuk melakukan perbuatan pencemaran dan atau perusakan lingkungan hidup dikriminalisasi menjadi suatu perbuatan pidana yang berdiri sendiri, maka kita telah selangkah lebih maju dalam mencegah terjadinya pencemaran dan atau perusakan lingkungan hidup;

17 Konsiderans huruf a Peraturan Mahkamah Agung Nomor 13 Tahun 2016 tentang Tata Cara Penanganan Perkara Tindak pidana oleh korporasi.

18 Peraturan Mahkamah Agung Nomor 13 Tahun 2016 tentang Tata Cara Penanganan Perkara Tindak Pidana Oleh Korporasi.

19 Soeseno Sigid, Hukum Pidana Indonesia, Perkembangan dan Pembaharuan (Implikasi Teori Pertanggungjawaban Pidana Korporasi dalam Perundang-undangan Pidana dan Praktik Peradilan Pidana Indonesia). Bandung: PT. Remaja Rosdakarya, 2013, hlm. 25. 
3. Dengan efek pencegahan sejak dini maka niat pelaku bisnis untuk melakukan pencemaran dan perusakan lingkungan hidup demi pertimbangan ekonomi dapat lebih ditekan, apalagi dengan sanksi-sanksi dalam bentuk denda diyakini lebih berdaya guna dalam mematikan motif ekonomi ini;

4. Dengan model penegakan hukum pidana administratif tersebut, maka kita dapat menuntun kepada terciptanya rezim anti pencemaran dan perusakan lingkungan hidup.

Dalam rangka penyusunan RUU PLH, tidak ada salahnya pemikiran di atas lebih dijadikan sebagai pertimbangan untuk dikembangkan sebagai model penegakan hukum lingkungan daripada berpikir untuk tetap mempertahankan atau tidak asas subsidaritas. Asas Subsidiaritas, melakukan tugas instansi lain agar tidak menimbulkan permasalahan yang lebih besar sebelum ditangani oleh institusi yang membidangi. Menurut Sadjijono bahwa asas subsidaritas hukum pidana menjadi pilihan terakhir ketika instrumen administrasi, perdata tidak terselesaikan maka fungsi pemidanaan diberlakukan. Tindak pidana lingkungan tidak terlebih dahulu dikedepankan untuk menyelesaikan persoalan lingkungan, apalagi terkait dengan persoalan korporasi yang melakukan perusakan lingkungan. Bentuk-bentuk atau jenisjenis sanksi yang dapat dijatuhkan kepada korporasi dapat berupa sanksi pokok dan sanksi tambahan. ${ }^{20}$ Asas subsidiaritas hukum pidana menjadi pilihan terakhir ketika instrument administrasi, perdata tidak terselesaikan.

Upaya pelanggaran oleh PT Jagat Raya Utama dengan melihat kondisi lingkungan sungai Wawonggura, Eewa, sungai Watumerembe, dan sungai Aosole. Limbah hasil operasi PT Jagat Raya Utama yang mengaliri sungai dapat dikategorikan pelanggaran batu mutu lingkungan. Seperti yang tertera pada Pasal 20 ayat 2 Undang-Undang 32 tahun 2009 tentang Perlindungan dan Pengelolaan Lingkungan Hidup. Baku mutu lingkungan hidup meliputi baku mutu air, baku mutu air limbah, baku mutu air laut, baku mutu udara ambiens, baku mutu emisi baku mutu gangguan dan baku mutu lainnya sesuai dengan perkembangan ilmu pengetahuan dan teknologi.

\section{Pertanggungjawaban Pidana PT Jagad Raya Tama Terhadap Pencemaran Lingkungan}

Titik tolak untuk mengkaji pertanggungjawaban pidana korporasi dalam hubungannya dengan pengabaian kewajiban. Kewajiban untuk menjaga lingkungan dimana perusahaan tersebut

20 Sutan Remi Sjahdeini, Pertanggungjawaban Pidana Korporasi, Cetakan II, Jakarta: Grafiti Pers, 2007, hlm. 205. 
mengelola lingkungan. PT Jagad Raya Tama merupakan perusahaan induk atau korporasi induk (parent company) yang memiliki anak perusahaan seperti perusahaan PT Bumi Putra Abadi dan PT Mitra Alam Makmur. Hal ini sesuai dengan Pasal 1 Peraturan Mahkamah Agung Nomor 13 Tahun 2016.21 Pasal 1 ayat 2 menyatakan: korporasi induk (parent company) adalah perusahaan berbadan hukum yang memiliki dua atau lebih anak perusahaan yang disebut perusahaan subsidiary yang juga memiliki status badan hukum sendiri.

Kemudian yang menjadi dasar pembenaran dapat dipidananya korporasi menurut C.M.V Clarckson sebagaimana yang dikutip oleh Kariawan Barus terdapat beberapa doktrin tentang sistem pertanggungjawaban pidana korporasi yaitu²2:

\section{Strict Liability}

Menurut doktrin ini, bila korporasi melakukan suatu perbuatan yang telah melanggar apa yang dirumuskan dalam suatu peraturan perundang-undangan, maka ia dapat dibebankan tanggung jawab atas perbuatan tersebut tanpa perlu dibuktikan apakah korporasi tersebut memenuhi unsur kesalahan (kesengajaan/kelalaian).

2. Vicarious Liability

Menurut doktrin ini, bila seseorang agen atau pekerja korporasi bertindak dalam lingkup pekerjaannya dan dengan maksud untuk menguntungkan korporasi, melakukan suatu kejahatan, tanggung jawab pidananya dapat dibebankan kepada perusahaan. Tidak menjadi masalah apakah perusahaan secara nyata memperoleh keuntungan atau tidak atau apakah aktivitas tersebut telah dilarang oleh perusahaan atau tidak.

3. Identification Doctrine

Menurut doktrin ini, bila seseorang yang cukup senior dalam struktur korporasi, atau dapat mewakili korporasi melakukan suatu kejahatan dalam bidang jabatannya, maka perbuatan dan niat orang itu dapat dihubungkan dengan korporasi. Korporasi dapat diidentifikasi dengan perbuatan ini dan dimintai pertanggungjawaban secara langsung.

4. Aggregation Doctrine

21 Peraturan Mahkamah Agung Nomor 13 Tahun 2016 tentang Tata Cara Penanganan Perkara Tindak Pidana Oleh Korporasi.

22 Kariawan Barus, Analisis Yuridis Pemidanaan Terhadap Korporasi Yang Melakukan Tindak Pidana Di Bidang Lingkungan Hidup Berdasarkan Undang-undang Nomor 32 Tahun 2009 Tentang Perlindungan Dan Pengelolaan Lingkungan Hidup (PPLH), Medan: Universitas Sumatera Utara, 2011, hlm. 92. 
Menurut pendekatan ini, tindak pidana tidak hanya bisa diketahui atau dilakukan oleh satu orang. Oleh karena itu, perlu mengumpulkan semua tindakan dan niat dari beberapa orang yang relevan dalam korporasi tersebut, untuk memastikan apakah secara keseluruhannya tindakan mereka akan merupakan suatu kejahatan atau senilai dengan apabila perbuatan dan niat itu dilakukan oleh satu orang.

\section{Reactive Corporate Fault}

Menurut pendekatan ini, suatu perbuatan yang merupakan tindak pidana dilakukan oleh atau atas nama sebuah korporasi, pengadilan harus diberi kewenangan untuk memerintahkan korporasi untuk melakukan investigasi sendiri guna memastikan orang yang bertanggung jawab dan mengambil suatu tindakan disiplin yang sesuai atas kesalahan orang tersebut dan mengambil langkah-langkah perbaikan untuk menjamin kesalahan tersebut tidak akan terulang kembali. Apabila korporasi mengambil langkah penanganan yang tepat, maka tidak ada tanggung jawab pidana yang dapat dijatuhkan terhadap korporasi. Tanggung jawab pidana hanya bisa diterapkan terhadap korporasi apabila korporasi gagal memenuhi perintah pengadilan dengan sungguh-sungguh. Dengan demikian, kesalahan korporasi bukanlah kesalahan pada saat kejahatan terjadi tetapi kesalahan karena korporasi gagal melakukan tindakan yang tepat atas kesalahan karena korporasi gagal melakukan tindakan yang tepat atas kesalahan yang dilakukan oleh pekerjanya.

\section{Management Failure Model}

Menurut pendekatan ini, bahwa kejahatan tanpa rencana (manslaughter) yang dilakukan oleh korporasi ketika ada kesalahan manajemen oleh korporasi yang menyebabkan seseorang meninggal dunia dan kegagalan tersebut merupakan perilaku yang secara rasional berada jauh dari yang diharapkan dilakukan oleh suatu korporasi. Kejahatan ini didefinisikan dengan mengacu ke kegagalan manajemen (sebagai lawan dari kegagalan korporasi).

\section{Corporate Mens Rea Doctrine}

Telah dikemukakan bahwa perusahaan itu sendiri tidak dapat melakukan kejahatan, mereka tidak dapat berpikir atau memiliki kemauan. Hanya orang-orang yang ada di dalam perusahaan yang dapat melakukan kejahatan. Namun demikian orang dapat menerima bahwa seluruh gagasan tentang personalitas korporasi adalah fiksi tetapi dibuat dengan baik dan sangat berguna. Berdasarkan pandangan ini, maka korporasi dapat diyakini sebagai agen yang melakukan kesalahan yang 
bertindak melalui staf mereka dan pekerja dan mens rea-nya dapat ditemukan dalam praktik dan kebijakan korporasi. Ini penting untuk ditekankan bahwa keduanya, yaitu kesembronoan (recklessness) atau maksud, dapat ditemukan di dalam kebijakan-kebijakan, operasional prosedur dan lemahnya tindakan pencegahan korporasi.

8. Specific Corporate Offences

Dalam hal ini, masalah-masalah yang berkaitan dengan penegasan tentang kesalahan korporasi, seperti pembuktian dari niat atau kesembronoan, dapat di atasi dengan membuat definisi khusus yang hanya dapat diterapkan kepada korporasi. Pada dasarnya lahirnya sebuah doktrin yang baru tidaklah menghilangkan atau menghapuskan doktrin sebelumnya namun menyempurnakannya. Demikian juga doktrin-doktrin yang dikemukakan berkaitan dengan pertanggungjawaban pidana korporasi.

Doktrin strict liability dan doktrin strict liability yang kemudian menjadi asas dalam hukum pidana Indonesia setelah diwujudkan dalam suatu norma tidaklah kemudian dihilangkan dengan adanya doktrin identifikasi. Disebabkan kemajuan perkembangan zaman maka perkembangan ilmu pengetahuan semakin maju pula. Dengan demikian penyempurnaan terhadap doktrin mengenai sistem pertanggungjawaban pidana akan terus disempurnakan agar terciptanya tujuan hukum yaitu keadilan, kepastian dan kemanfaatan. ${ }^{23}$

\section{KESIMPULAN}

Bentuk pertanggungjawaban pidana korporasi PT Jagat Raya Tama menyangkut persoalan pencemaran lingkungan berdasarkan Konsep Konservasi Lingkungan berdasarkan fakta di lapangan tidak terlaksana berdasarkan pelanggaran yang sudah memenuhi unsur dalam Undang-Undang 32 tahun 2009. Lemahnya penegakkan hukum oleh penegak hukum dan pemerintah di Konawe Selatan sehingga pelanggaran lingkungan PT Jagat Raya Tama terkesan dikesampingkan sementara Ketentuan pemidanaan telah diatur berdasarkan Undang- Undang pengelolaan lingkungan hidup terdapat pada Pasal 97 sampai dengan Pasal 120. Dalam Pasal 100 UUPLH menyatakan: Setiap orang yang melanggar baku mutu air limbah, baku mutu emisi, atau baku mutu gangguan dipidana dengan penjara paling lama 3 tahun dan denda paling

23 Elly Syafitri Harahap, Alvi Syahrin, Mahmud Mulyadi, “Asas Strict Liability Dan Asas Vicarious Liability Terhadap Korporasi Yang Melakukan Tindak Pidana Berdasarkan Undang-Undang Nomor 32 Tahun 2009 Tentang Perlindungan Dan Pengelolaan Lingkungan Hidup", Jurnal Mahupiki, Vol 2, No 1, 2014, hlm. 14. 
banyak 3.000.000.000,- (tiga milyar). Pada pidana tambahan juga tidak dilaksanakan seperti: Perampasan keuntungan yang diperoleh dari tindak pidana belum terdapat pengaturan lebih tegas mengenai manfaat dan peruntukan perampasan keuntungan yang dimaksud. Penutupan seluruh atau sebagian tempat usaha dan/atau kegiatan sebenarnya dapat juga dijatuhkan melalui sanksi administrasi yaitu pencabutan izin usaha melalui Pengadilan Tata Usaha Negara.

Penerapan asas subsidaritas dalam kejahatan korporasi tidak bisa lagi digunakan. Rujukan ada pada Peraturan Mahkamah Agung Nomor 13 Tahun 2016 tentang Tata Cara Penanganan Perkara Tindak Pidana Oleh Korporasi.

\section{Daftar Pustaka}

\section{Buku}

Barus, Kariawan, Analisis Yuridis Pemidanaan Terhadap Korporasi Yang Melakukan Tindak Pidana Di Bidang Lingkungan Hidup Berdasarkan Undang-undang Nomor 32 Tahun 2009 Tentang Perlindungan Dan Pengelolaan Lingkungan Hidup (PPLH), Medan: Universitas Sumatera Utara, 2011.

Fahruddin, Pengelolaan Limbah Pertambangan Secara Biologis: Biological Management of Mining Waste, Makassar: Celebes Media Perkasa, 2018.

Fuady, Munir, Teori Besar (Grand Theory) Dalam Hukum, Jakarta: Kencana, 2013.

Marzuki, Peter Mahmud, Penelitian Hukum, Jakarta: Kencana, 2008.

Rangkuti, Siti Sundari, Hukum Lingkungan dan Kebijaksanaan Lingkungan Nasional, Cetakan III, Surabaya: Airlangga University Press, 2003.

Sigid, Soeseno, Hukum Pidana Indonesia, Perkembangan dan Pembaharuan (Implikasi Teori Pertanggungjawaban Pidana Korporasi dalam Perundang-undangan Pidana dan Praktik Peradilan Pidana Indonesia). Bandung: PT. Remaja Rosdakarya, 2013.

Sjahdeini, Sutan Remi, Pertanggungjawaban Pidana Korporasi, Cetakan II, Jakarta: Grafiti Pers, 2007.

Topan, Muhammad, Kejahatan Korporasi Dibidang Lingkungan Hidup, Cet: I, Bandung: Nusa Media, 2009.

\section{Jurnal dan Makalah}

Harahap, Elly Syafitri, Alvi Syahrin, Mahmud Mulyadi, “Asas Strict Liability Dan Asas Vicarious Liability Terhadap Korporasi Yang Melakukan Tindak Pidana Berdasarkan Undang- 
Undang Nomor 32 Tahun 2009 Tentang Perlindungan Dan Pengelolaan Lingkungan Hidup", Jurnal Mahupiki, Vol 2, No 1, 2014.

Haris, Oheo K., “Aspek Hukum Pidana Dalam Kaitannya Dengan Perizinan Di Bidang Pertambangan". Jurnal Yuridika, Volume 29 No. 3, September-Desember 2014.

Hidayat, Sabrina, "Tinjauan Yuridis Kewenangan Komisi Pemberantasan Korupsi Melakukan Penyidikan Penggabungan Perkara Tindak Pidana Korupsi dan Pencucian Uang”. Halu Oleo Law Review, Volume 1 Issue 2, September 2017.

Suharyanto, Budi, "Pertanggungjawaban Pidana Korporasi Berdasarkan Corporate Culture Model dan Implikasinya", Jurnal Rechtsvinding, Volume 6, Nomor 3, Desember 2017.

Sukamdani, Hariyadi B., Korporasi sebagai Subyek Hukum Pidana Pasca Perma No.13 Tahun 2016: Pandangan Dunia Usaha, Makalah seminar dalam Rangka HUT IKAHI ke-64 tahun di Hotel Mercure Ancol Jakarta pada hari Selasa 21 Maret 2017.

\section{Peraturan Perundang-undangan}

Undang-Undang Dasar Negara Republik Indonesia 1945

Undang-Undang Republik Indonesia Nomor 31 Tahun 1999 Tentang Pemberantasan Tindak Pidana Korupsi (Lembaran Negara Republik Indonesia Tahun 1999 Nomor 140, Tambahan Lembaran Negara Republik Indonesia Nomor 3874)

Undang-Undang Republik Indonesia Nomor 20 Tahun 2001 Tentang Perubahan Atas UndangUndang Republik Indonesia Nomor 31 Tahun 1999 Tentang Pemberantasan Tindak Pidana Korupsi (Lembaran Negara Republik Indonesia Tahun 2001 Nomor 134, Tambahan Lembaran Negara Republik Indonesia Nomor 4150)

Undang-Undang Republik Indonesia Nomor 40 Tahun 2007 tentang Perseroan Terbatas (Lembaran Negara Republik Indonesia Tahun 2007 Nomor 106, Tambahan Lembaran Negara Republik Indonesia Nomor 4756).

Undang-Undang Republik Indonesia Nomor 4 Tahun 2009 Tentang Pertambangan Mineral Dan

Batubara (Lembaran Negara Republik Indonesia Tahun 2009 Nomor 4, Tambahan Lembaran Negara Republik Indonesia Nomor 4959)

Undang-Undang Republik Indonesia Nomor 32 Tahun 2009 Tentang Perlindungan dan Pengelolaan Lingkungan Hidup (Lembaran Negara Republik Indonesia Tahun 2009 Nomor 140, Tambahan Lembaran Negara Republik Indonesia Nomor 5059) 
Peraturan Pemerintah Nomor 27 Tahun 2009 Tentang Analisis Mengenai Dampak Lingkungan (Lembaran Negara Republik Indonesia Tahun 2009 Nomor 59, Tambahan Lembaran Negara Republik Indonesia Nomor 4993)

Peraturan Pemerintah Republik Indonesia Nomor 27 Tahun 2012 Tentang Izin Lingkungan (Lembaran Negara Republik Indonesia Tahun 2012 Nomor 48, Tambahan Lembaran Negara Republik Indonesia Nomor 5285)

Peraturan Mahkamah Agung Nomor 13 Tahun 2016 tentang Tata Cara Penanganan Perkara Tindak Pidana Oleh Korporasi

Peraturan Menteri Negara Lingkungan Hidup Nomor 5 Tahun 2012 Tentang Jenis Rencana Usaha Dan/Atau Kegiatan Yang Wajib Dilengkapi Dengan Analisis Mengenai Dampak Lingkungan Hidup

Keputusan Menteri Energi Dan Sumber Daya Mineral Republik Indonesia Nomor 1827 K/30/MEM/2018 Tentang Pedoman Pelaksanaan Kaidah Teknik Pertambangan yang Baik 